Short communication

\title{
MORPHOLOGICAL CHARACTERISTICS OF THREE CLASSIC FORMS OF NATURAL EQUINE GLANDERS - A DISEASE WITH HIGH ZOONOTIC SIGNIFICANCE
}

\author{
ANIČIĆ Milan*, KUKOLJ Vladimir, MARINKOVIĆ Darko \\ Department of Pathology, Faculty of Veterinary Medicine University of Belgrade, Belgrade, Serbia
}

(Received 17 October, Accepted 29 November 2017)

\begin{abstract}
Equine glanders is a severe bacterial disease known since ancient times. Although eradicated in the most part of the world it is now considered re-emerging. Considering very scarce literature data, we used from formalin fixed collection material: nasal septum, lung and skin specimens from naturally infected horses. Tissues were grossly examined and photographed. Tissue samples, after standard processing, were stained with HE, Congo red and Groccot and microscopically examined. Gross changes include nodules and ulcers in the nasal mucosa with granulation and scarring, pyogranulomas in the lung tissue and nodules and ulcers of the skin. Microscopically marked inflammation of affected tissues with neutrophilic and mononuclear infiltration and fibrous tissue proliferation were seen. As a potent zoonotic agent it has been already used as a biological weapon in the past.
\end{abstract}

Key words: glanders, equine, gross, microscopic changes

\section{INTRODUCTION}

Glanders (equinia, malleus, farcy) is an infectious, zoonotic disease of solipeds (horses, mules and donkeys) caused by Burkholderia mallei, a bacterium which primarily affects skin, lymphatics and the respiratory tract with the formation of nodules and ulcerations [1]. Although it has been eradicated in most parts of the world it is still endemic in the Middle East, Asia, Africa and South America [2-4]. Due to numerous recent outbreaks (Brazil, Turkey, Ethiopia, Iran, Iraq, UAE, Mongolia, India, Pakistan) it is considered a re-emerging disease $[1,2,5]$. Besides domestic equids, many other species are susceptible to glanders. Reports describe animals were infected after eating glanderous meat or being in close proximity of a glanderous animal [5,6]. Laboratory animals also can be naturally infected [7]. Cattle and pigs seem to be resistant, even after experimental infection [8]. Equine glanders manifests in three clinical forms: pulmonary, nasal and cutaneous, which often coincide and thus make them indistinguishable [5]. Al-Ani and colleagues proposed that asymptomatic carriers should be recognized as the fourth form of the disease [9]. Burkholderia mallei has a significant zoonotic potential due to the

\footnotetext{
*Corresponding author: e-mail: anicicm@vet.bg.ac.rs
} 
high mortality rate in humans and a small number of organisms required to establish infection [7]. As a serious biological weapon and potential agent of bioterrorism it is listed as a category B biothreat agent by the Center for Disease Control and Prevention (CDC), Atlanta, Georgia, USA [10]. Due to its reappearance we thought it should be beneficial to recall major gross and histopathological changes in natural glanders.

\section{MATERIALS AND METHODS}

We used formalin fixed tissues which derived from naturally infected horses. These are part of the collection of the Museum of Archives, Department of Pathology, Faculty of Veterinary Medicine, University of Belgrade, Serbia. Tissues were examined grossly, photographed and samples for histopathology were taken. After standard processing in an automated tissue processor, tissue samples were embedded in paraffin blocks and $5 \mu \mathrm{m}$ thick sections were stained with hematoxylin and eosin (HE), Congo red and Groccot. The results of histochemical staining were analyzed by light microscope (BX51, Olympus Optical, Japan), and pictures were taken with Olympus Color View III ${ }^{\circledR}$ digital camera.

\section{RESULTS AND DISCUSSION}

The main morphological manifestation of natural equine glanders comprised nasal, pulmonary and skin lesions. The nasal form begins with the formation of miliary nodules in the mucosa covered with intact epithelium. Due to necrosis they become easily visible, gray to yellow, surrounded by a narrow hyperemic halo. Soon after, nodules ulcerate releasing a mucopurulent to haemorrhagic discharge. After demarcation and removal of necrotic mucosa ulcer borders become flat and smooth - which gives them a perforated, lenticular appearance (lenticular glanders, malleus lenticularis) [11]. Larger secondary ulcers are formed either by lymphatic resorption or coalescing of primary ulcers. These ulcers are deep, with raised, serrated edges and a fine granulated bottom (Figure 1A). Sometimes they invade the turbinates and cartilaginous structures, leading to perforation of the nasal septum. After demarcation and clearance of necrotic tissue and debris, defects heal and granulation tissue proliferates with the formation of scars. These fibrous scars are white, raised, radial or star (stellate) shaped and look a bit like „frost flowers" (Figure 1B). All of these changes can be seen in the same animal [11]. Similar, mainly ulcerative, lesions can be seen in the laryngeal, pharyngeal and tracheal mucosa.

The pulmonary form is the most common clinical manifestation (up to $90 \%$ of infected horses), characterized by pyogranulomatous nodules throughout the pulmonary tissue [5]. They form as discrete, round, gray whitish, almost transparent miliary nodules with hyperemic borders. With necrotic alterations in the center, they become blurry yellowish and distinct (Figure 2A). They confluate and become larger, solid and resemble fibrous tissue (malleosis fibroplastica) [11]. Dystrophic calcification 
can occur. These glanderous nodes can confluate even more leading to lobular or lobar suppurative pneumonia with marked perifocal edema. Reactive granulation follows and large areas of fibrous tissue form, with characteristic inner structure consisted of cavernae filled with necrosuppurative detritus. Pleuritis is common [11].
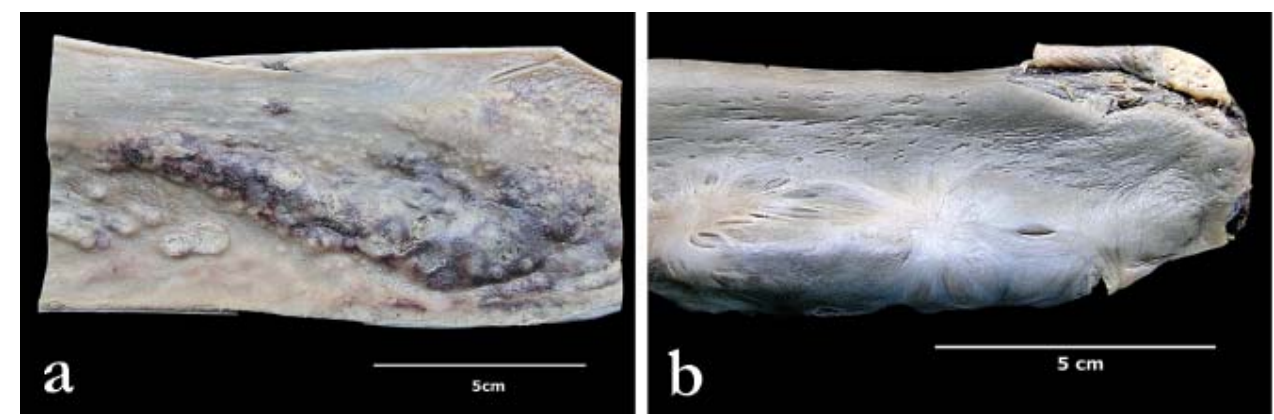

Figure 1. Macroscopic changes in nasal mucosa of a horse. a) acute form with nodules, nodes and ulcers of different size; b) chronic form with scaring ("frost flowers")

In the cutaneous form (farcy) there are nodular and ulcerative lesions of the skin. Nodules, round to oval, from few millimeters to $2 \mathrm{~cm}$ in diameter, appear along the lymphatic vessels as a ,string of pearls" [5]. Cutting of these nodes reveals a necrotic center and pus surrounded with a fibrous capsule. They may erupt (burst), exuding viscid pus and leaving crateriform ulcers which are slow to heal (Figure 2B). Lymphatic vessels are swollen and thick, solid and can be traced to lymph nodes (cording of the lymphatics). Draining lymph nodes are enlarged and bulge on the cut surface. These may also rupture and suppurate. In protracted cases they become firm and indurated [11].
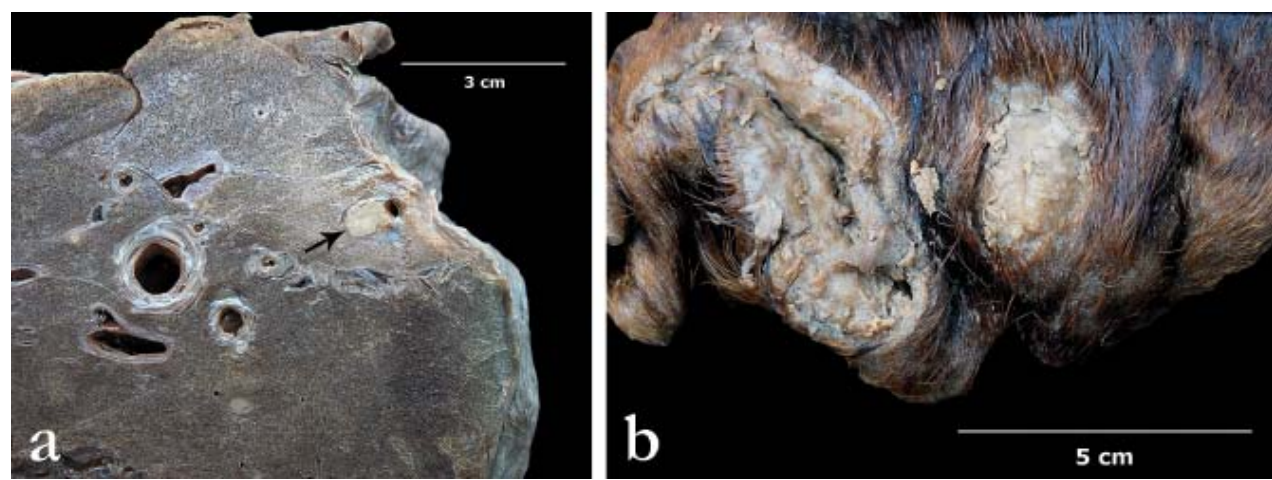

Figure 2. Macroscopic changes in lungs and skin of a horse. a) well demarcated pyogranuloma in subpleural pulmonary parenchyma (arrow); b) multiple crateriform skin ulcers.

Hematogenous metastatic dissemination results in glanderous nodules and nodes in various visceral organs, commonly spleen, liver, kidneys and testicles, which, if not suppurated, can be mistaken for sarcomatous proliferations [5,11]. 
Histopathologic lesions include marked vasculitis and thrombosis in the upper airways with infiltration of neutrophilic granulocytes and macrophages (Figure 3A), pyogranulomatous nodules in the lungs and suppurative lymphadenitis and lymphangitis with leukocyte necrosis [12]. Nasal lesions heal with a formation of a large amount of mature fibrous tissue (Figure 3B). Lung nodules consist of necrosuppurative cores which contain liquefied tissue and a large number of neutrophils, many of them with necrobiotic changes, periferal rim of epitheloid cells, giant cells and lymphocytes, encapsulated with fibrous tissue (Figure 4). Hemorrhage, edema, intra-alveolar fibrin or dystrophic calcification may be seen. Nodules found in visceral organs microscopically are similar to pulmonary nodules [1]. Neither of the samples stained with Groccot or Congo red.

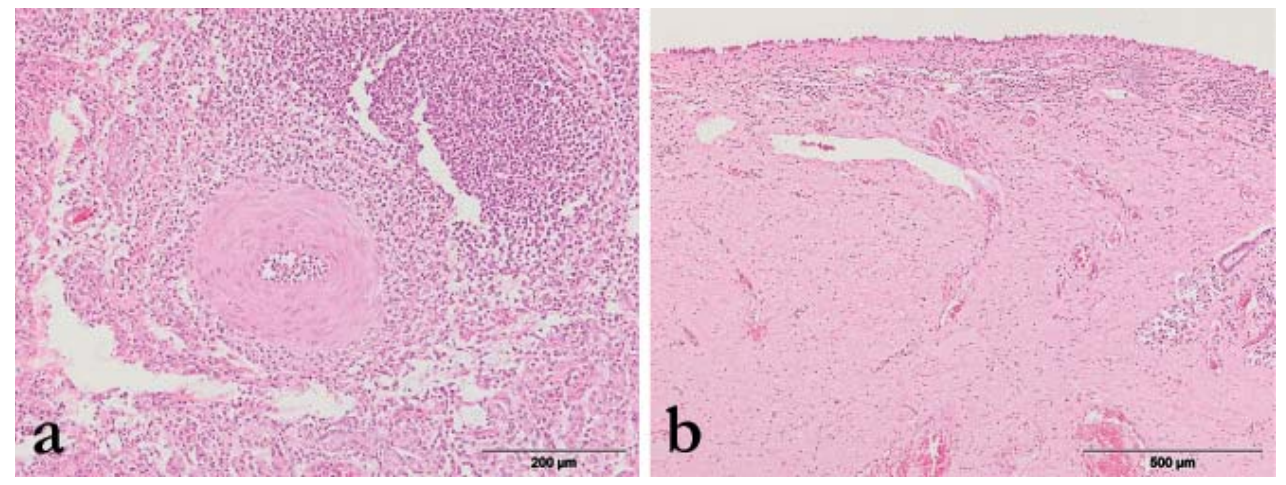

Figure 3. Microscopic changes in nasal mucosa of a horse. a) acute form characterized by marked perivascular infiltration of neutrophil granulocytes and macrophages, HE; b) large ammount of mature fibrous tissue, partially infiltrated with mononuclear cells and hyperemic blood vessels, HE.
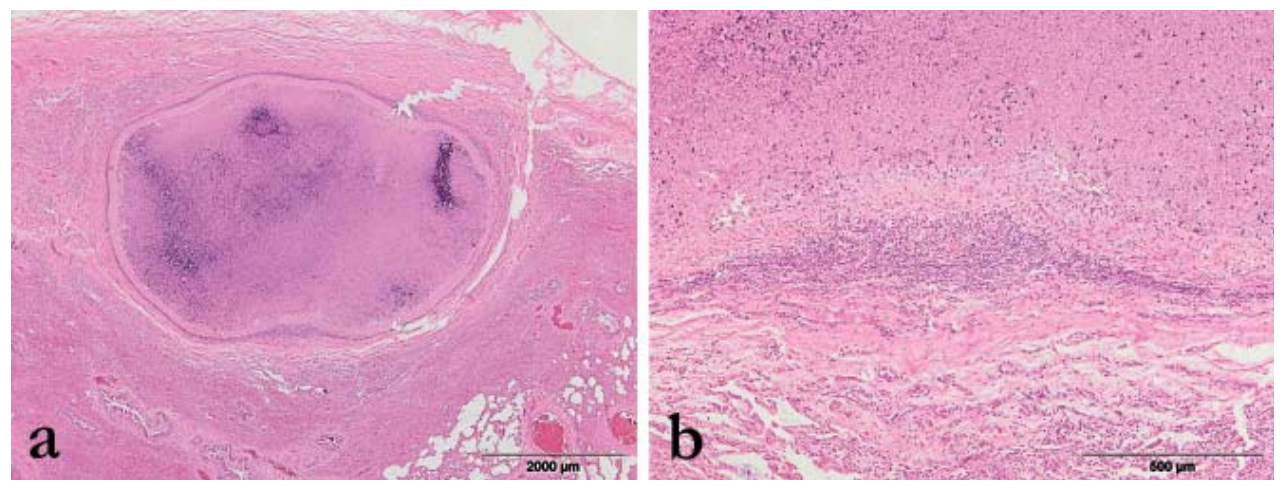

Figure 4. Microscopic changes in lungs of a horse. a) well demarcated pyogranuloma with necrotic center and calcification, HE; b) detail from figure a, mononuclear infiltration in the demarcation zone between pyogranuloma and normal lung tissue HE.

Due to the abscence of pathognomonic morphological characteristics differential diagnostics should include strangles, nasal amyloidosis, ulcerative lymphangitis, 
epizootic lymphangitis, sporotrichosis, botryomycosis, horsepox, tuberculosis, pseudotuberculosis, melioidosis and allergy.

\section{Authors' contributions}

AM drafted the manuscript, carried out literature research and carried out histopathological studies, KV examined and described gross lesions, took photography and helped to draft the manuscript, MD carried out histopathological studies and critically revised the manuscript. All authors read and approved the final manuscript.

\section{Declaration of conflicting interests}

The author(s) declared no potential conflicts of interest with respect to the research, authorship, and/or publication of this article.

\section{REFERENCES}

1. Verma AK, Saminathan M, Neha, Tiwari R, Dhama K, Singh SV: Glanders - a re-emerging zoonotic disease: a review. J Biol Sci 2014, 14:38-51.

2. Dvorak GD, Spickler AR: Glanders. JAVMA 2008, 233:570-577.

3. World Organization for Animal Health (OIE): World Animal Health Information Database (WAHIS Interface). [http://www.oie.int/wahis_2/public/ wahid.php/ Diseaseinformation/Diseaseoutbreakmaps/Glanders]

4. Al-Ani FK, Roberson J: Glanders in horses: a review of the literature. Veterinarski Arh 2007, 77:203-218.

5. Khan I, Wieler LH, Melzer F, Elschner MC, Muhammad G, Ali S, Sprague LD, Neubauer $\mathrm{H}$, Saqib M: Glanders in animals: a review on epidemiology, clinical presentation, diagnosis and countermeasures. Transbound Emerg Dis 2012, 60:204-221.

6. Wernery U, Wernery R, Joseph M, Al-Salloom F, Johnson B, Kinne J, Jose S, Tappendorf B, Hornstra H, Scholz C: Natural Burkholderia mallei infection in dromedry, Bahrain. Emerg Infect Dis 2011, 7:1277-1279.

7. Gregory BC, Waag DM: Glanders. In: Medical aspects of biological warfare. Washington DC, USA: Borden Institute, Walter Reed Army Medical Center; 2007, 121-146.

8. World Organization for Animal Health (OIE): Glanders. In: Manual of diagnostic tests and vaccines for terrestrial animals 2015. [http://www.oie.int/fileadmin/Home/eng/Health_ standards/tahm/2.05.11_GLANDERS.pdf]

9. Al-Ani FK, Al-Delami AK, Ali AH: Glanders in horses: clinical and epidemiological studies in Iraq. Pakistan Vet J 1987, 79:126-129.

10. Rotz LD, Khan AS, Lilibridge SR, Astroff SM, Hughes JM: Public health assessment of potential biological terrorism agents. Emerg Infect Dis 2002, 2:225-230.

11. Sofrenovic Dj, Knezevic N: Sakagija (malleus). In: Basic pathological characteristics of important infectious diseases of domestic animals (In Serbian). Belgrade, Serbia: Veterinary Chamber of Serbia; 1994, 179-183.

12. Arun S, Neubauer H, Gürel A, Ayyildiz G, Kuscu, Yesildere T, Meyer H, Hermanns W: Equine glanders in Turkey. Vet Rec 1999, 144:255-258. 


\title{
MORFOLOŠKE KARAKTERISTIKE TRI KLASIČNE FORME SAKAGIJE KOD PRIRODNO INFICIRANIH KONJA - BOLEST OD VISOKOG ZOONOTSKOG ZNAČAJA
}

\author{
ANIČIĆ Milan, KUKOLJ Vladimir, MARINKOVIĆ Darko
}

Sakagija (maleus) predstavlja značajnu zoonozu, poznatu od davnina. Iako iskorenjena u većem delu sveta danas se smatra bolešću koja se ponovo širi. Imajući u vidu oskudne podatke iz literature, koristili smo iz kolekcije fiksiranog tkiva: nosnu pregradu, pluća i kožu koji potiču od prirodno inficiranih konja. Tkiva su pregledana, opisana i fotografisana. Nakon standardne obrade uzorci tkiva su bojeni HE, Congo red i Groccot metodama bojenja. Makroskopske promene su obuhvatale nodule i ulceracije na nosnoj sluznici sa razvojem ožiljnog tkiva, piogranulome u plućima i nodule i ulcere na koži. Histološki se uočava izražena inflamacija sa velikom količinom neutrofilnih granulocita i mononuklearnih ćelija, kao i proliferacija vezivnog tkiva. Zbog zoonotskog karaktera uzročnik sakagije se danas ponovo proučava kao potencijalno biološko oružje, već korišćeno u prošlosti. 